\title{
Diptheroid Bacillus
}

National Cancer Institute

\section{Source}

National Cancer Institute. Diptheroid Bacillus. NCI Thesaurus. Code C86343.

Any of a number of rod shaped bacteria that resemble Corynebacterium diphtheriae, either in morphology or etiology. 